\title{
Orthotopic tumorgrafts in nude mice as a model to evaluate calcitriol effects in breast cancer
}

\author{
V. C. N. Fonseca-Filho ${ }_{\S}$, M. L. H. Katayama $a_{\S}$, E. C. Lyra ${ }^{b}$, D. A. Maria ${ }^{c}$, R. A. Basso ${ }^{b}$, \\ S. Nonogakid, J. M. Guerra ${ }^{d}$, S. Maistro ${ }^{a}$, J. C. G. S. Góes ${ }^{b}$ and M. A. A. K. Folgueira * \\ ${ }^{a}$ Centro de Investigação Translacional em Oncologia, Instituto do Câncer do Estado de São Paulo, Departamento de \\ Radiologia e Oncologia, Hospital das Clínicas, Faculdade de Medicina, Universidade de São Paulo - USP, \\ Avenida Dr. Arnaldo, 251, Cerqueira César, CEP 01246-000, São Paulo, SP, Brazil \\ bDepartamento de Mastologia, Instituto Brasileiro de Controle do Câncer - IBCC, Avenida Alcântara Machado, 2576, \\ Parque da Mooca, CEP 03102-002, São Paulo, SP, Brazil \\ 'Serviço de Bioquímica, Divisão de Ciências Fisiológicas e Químicas, Instituto Butantan, Avenida Vital Brasil, 1500, \\ Butantã, CEP 05503-900, São Paulo, SP, Brazil \\ dDepartamento de Patologia, Instituto Adolfo Lutz - IAL, Avenida Dr. Arnaldo 355, Cerqueira César, \\ CEP 01246-000, São Paulo, SP, Brazil \\ $\S$ VCNFF, MLHK, ECL participated equally in the work. \\ *e-mail: maria.folgueira@fm.usp.br
}

Received: March 28, 2016 - Accepted: July 12, 2016 - Distributed: November 31, 2017 (With 7 figures)

\begin{abstract}
Calcitriol antiproliferative effects were observed in xenografts of breast cancer cell lines, however they were not yet investigated in tumorgrafts, consisting of freshly collected breast cancer samples xenografted into animals. Objectives: To establish a tumorgraft model, from freshly collected breast cancer samples, which were directly implanted in nude mice, to study calcitriol effects. Methods: Breast cancer samples collected from 12 patients were orthotopically implanted into nude mice. Animals were treated with weekly intratumoral injections of calcitriol $3 \mu \mathrm{g} / \mathrm{Kg}$, which was previously shown to induce peak serum calcitriol levels in the predicted therapeutic range. Results: Success engraftment rate was $25 \%$. Tumorgrafts were established from aggressive (HER2 positive or histological grade 3 ) highly proliferative samples and original tumor characteristics were preserved. Calcitriol highly induced its target gene, CYP24A1, indicating that the genomic vitamin D pathway is active in tumorgrafts. However, no differences in the expression of proliferation and apoptosis markers (BrdU incorporation, Ki67, CDKN1A, CDKN1B, BCL2 expression) were observed in these highly proliferative tumor samples. Conclusions: Tumorgrafts seem a promising model to explore other calcitriol doses and regimens, considering the heterogeneity of the disease and microenvironment interactions.
\end{abstract}

Keywords: tumorgraft, breast cancer, calcitriol, proliferation.

\section{Modelo de enxerto tumoral ortotópico em camundongos para avaliar os efeitos do calcitriol em câncer de mama}

\section{Resumo}

Os efeitos antiproliferativos de calcitriol foram observados em xenotransplantes de linhagens celulares de câncer de mama, entretanto, não foram ainda investigados em enxertos tumorais, consistindo de implantes em animais de amostras de câncer de mama recém-coletadas. Objetivos: Estabelecer modelo de enxerto tumoral, a partir de amostra de câncer de mama recém-coletada e diretamente implantada em camundongos nude, para estudar o efeito do calcitriol. Métodos: Amostras de câncer de mama de 12 pacientes foram implantadas ortotopicamente em camundongos nude. Os animais foram tratados com injeção intratumoral semanal de calcitriol $3 \mu \mathrm{g} / \mathrm{Kg}$, a qual foi previamente associada com indução de pico sérico de calcitriol dentro do intervalo de nível terapêutico. Resultados: A taxa de sucesso de pega do enxerto foi de $25 \%$. Os enxertos tumorais foram estabelecidos de tumores agressivos com alta taxa de proliferação (HER2 positivo ou grau histológico 3) e as características do tumor original foram preservadas. O calcitriol induziu fortemente a expressão do gene alvo, CYP24A1, indicando que a via genômica da vitamina D está ativa nos enxertos tumorais, entretanto, não se observou diferenças na expressão de marcadores de proliferação e apoptose (incorporação de BrdU, expressão de Ki67, CDKN1A, CDKN1B e BCL2) nestas amostras altamente proliferativas. Conclusões: Os enxertos tumorais parecem ser um modelo promissor para explorar outros esquemas e doses de calcitriol, considerando a heterogeneidade da doença e interações com o microambiente.

Palavras-chave: enxerto, câncer de mama, calcitriol, proliferação. 


\section{Introduction}

A relationship between decreased exposure to sunlight and reduced synthesis of vitamin D on the skin with higher breast cancer incidence and mortality was previously suggested (Garland et al., 2006). To clarify this issue, a few studies have directly assessed the relationship between vitamin D serum concentration and breast cancer risk. Although some studies indicate that vitamin D levels are inversely correlated with breast cancer risk, recent meta-analyses show the opposite findings, if the analysis were restricted to prospective studies measuring $25(\mathrm{OH})$ $\mathrm{D}$ years before diagnosis or evaluated pre-diagnostic $25(\mathrm{OH}) \mathrm{D}_{3}$ concentrations in older individuals. (BertoneJohnson et al., 2005; Abbas et al., 2008; Wang et al., 2013; Janowsky et al., 1999; Lyra et al., 2006; Hiatt et al., 1998; Gandini et al., 2011; Ordóñez-Mena et al., 2015; Yin et al., 2010). In addition, while $25(\mathrm{OH}) \mathrm{D}_{3}$ deficiency was associated with poor outcome in observational studies (Goodwin et al., 2009), no prognostic association of 25 hydroxy vitamin D in a phase III adjuvant randomized clinical trial of chemotherapy regimens in high-risk breast cancer patients was observed (Lohmann et al., 2015). Hence, some controversies are still in place regarding the association between $25(\mathrm{OH}) \mathrm{D}_{3}$ level and breast cancer risk and prognosis.

A possible link between the vitamin D pathway and breast cancer development was reported as an amplification of CYP24A1, that codes for 24-hydroxylase, an enzyme responsible for $1,25(\mathrm{OH})_{2} \mathrm{D}_{3}$ hydroxilation, and its consequent lower activity (Albertson et al., 2000). On the other hand, CYP27B1 expression, which codes for $1 \alpha$-hydroxylase, was detected in normal human breast, as well as in breast carcinoma samples, indicating that local activation of the precursor form, $25(\mathrm{OH}) \mathrm{D}_{3}$, may take place in both normal and cancerous tissues (Lyra et al., 2006; Lopes et al., 2010). In addition, receptors for $1,25(\mathrm{OH})_{2} \mathrm{D}_{3}$ were identified in breast cancer cell lines and breast cancer specimens (Lyra et al., 2006; Bortman et al., 2002). Hence, the vitamin D pathway may be a possible antitumoral target in breast cancer.

The mechanism underlying $1,25(\mathrm{OH})_{2} \mathrm{D}_{3}$ induced $\mathrm{G} 0 / \mathrm{G} 1$ phase growth arrest involves up-regulation of molecules like cyclin dependent kinase inhibitors such as $\mathrm{p} 21^{\mathrm{WAF} 1 / \mathrm{CIP} 1}$ (CDKN1A) and p27 ${ }^{\text {IIP1 }}$ (CDKN1B) (Verlinden et al., 1998; Katayama et al., 2003), as well as transforming growth factor $\beta$, TGF $\beta$ (which can inhibit the proliferation of epithelial cells), TGF $\beta$ receptors and insulin-like growth factor binding protein-3 (IGFBP-3), which regulates the availability of insulin-like growth factor (IGF), an important mitogen for normal mammary epithelial and breast cancer cells (Swami et al., 2003). Most of these studies however, were performed in breast cancer cell lines, an experimental model that does not take into consideration the epithelial mesenchymal interactions on the tumor microenvironment.

Stromal cells, that infiltrate and surround the malignant cells, were also shown to be vitamin D targets, as they also express vitamin D receptor (VDR) (Campos et al.,
2013; Knower et al., 2013). In agreement, our previous studies have shown that in cultured breast cancer fresh slices, transcriptional response to $1,25(\mathrm{OH})_{2} \mathrm{D}_{3}$ seems to reflect both cell compartments, epithelial as well as stromal (Milani et al., 2013). In this experimental model, $1,25(\mathrm{OH})_{2} \mathrm{D}_{3}$ at near physiological concentration $(0.5 \mathrm{nM})$ could activate the hormone genomic pathway, detected through the induction of CYP24A1 expression. The overall transcriptional response was concentration related and less intense than in tumor samples treated with $1,25(\mathrm{OH})_{2} \mathrm{D}_{3}$ at $100 \mathrm{nM}$. Transcriptional effects however, were not reproducible in post-menopausal breast cancer patients and the genomic pathway was not induced in tumor specimens collected after a short period of calcitriol supplementation $(0.5 \mu \mathrm{g} / \mathrm{PO} /$ day for 30 days) (Urata et al., 2014).

Phase I studies revealed that pulse administration may allow higher calcitriol oral or subcutaneous doses without major toxicities (Smith et al., 1999; Beer et al., 2001). It was also shown that, calcipotriol, a vitamin D3 analogue, when locally applied on breast cancer skin metastasis, as an ointment, may induce a few partial and minor responses (Bower et al., 1991).

We have then tried to establish a tumorgraft model from freshly collected breast cancer samples in nude mice to study calcitriol effects. Our hypothesis was that intra-tumoral administration of calcitriol might provide a high local concentration of the hormone, that besides activating the genomic pathway, might impact on tumor proliferation, without major toxicities as hypercalcemia. This preclinical experimental model might contribute to explore calcitriol effects considering the heterogeneity of the disease and microenvironment interactions.

\section{Patients and Methods}

\subsection{Patients}

Post-menopausal breast cancer patients were invited to participate in this study, which was approved by the Institutional Ethics Committee (Comissão de Trabalhos Científicos do Instituto Brasileiro de Controle do Câncer-IBCC, in August 06, 2010; Comitê de Ética em Pesquisa da Faculdade de Medicina da USP, protocolo 088/11).

Twelve patients agreed to take part in the study and signed a written informed consent. Median age of the patients was 57.5 years, most of whom, diagnosed with invasive ductal carcinomas (91.6\%) histological grade II $(58.3 \%)$ (Table 1$)$. No patients received neoadjuvant treatment and tumor fragments were collected during breast surgery.

\subsection{Establishment of tumorgrafts in female nude mice}

Mice procedures were performed in compliance with the Canadian Council on Animal Care with approval from the Institutional Ethics Committee (Comitê de Ética em Pesquisa da Faculdade de Medicina da USP, protocolo 088/11; Comissão de Ética no Uso de Animais do Instituto Butantan, protocolo 759/10). 
Table 1. Characteristics of patients.

\begin{tabular}{ccccccccc}
\hline $\begin{array}{c}\text { Tumor } \\
\text { sample }\end{array}$ & $\begin{array}{c}\text { Age } \\
\text { (years) }\end{array}$ & CS & HT & HG & $\begin{array}{c}\text { ER } \\
\mathbf{( \% )}\end{array}$ & $\begin{array}{c}\text { PR } \\
(\mathbf{\%})\end{array}$ & HER2 & $\begin{array}{c}\text { Ki67 } \\
(\%)\end{array}$ \\
\hline T1 & 65 & IIB & IDC & 2 & 20 & 30 & neg & ND \\
T3 & 63 & IIA & IDC & 2 & 30 & 40 & neg & 12 \\
T7 & 50 & IIA & IDC & 3 & 50 & 30 & neg & 80 \\
T8 & 74 & IA & IDC & 2 & 70 & neg & neg & 5 \\
T9 & 53 & IIA & IDC & 2 & 10 & 10 & pos & 10 \\
T10 & 51 & IIB & IDC & 3 & 10 & neg & neg & 35 \\
T11 & 51 & IIA & IDC & 2 & neg & neg & pos & 30 \\
T12 & 64 & IIA & IDC & 3 & neg & neg & neg & 40 \\
T13 & 55 & IIA & IDC & 2 & neg & 01 & neg & 55 \\
T14 & 68 & IA & MC & 2 & 90 & 75 & neg & 15 \\
T16 & 57 & IIIB & IDC & 3 & 10 & 40 & neg & 50 \\
T17 & 58 & IIA & IDC & 3 & 9 & neg & neg & 99 \\
T18 & 62 & IA & IDC & 2 & 50 & 80 & neg & ND \\
T19 & 68 & IA & IDC & 2 & 80 & 70 & pos & 30 \\
\hline
\end{tabular}

CS: clinical stage; HT: histological type, IDC: invasive ductal carcinoma, MC: mucinous carcinoma; HG: histological grade; ER: estrogen receptor; PR: progesterone receptor; pos: positive; neg: negative. (HER2: Herceptest and/or FISH); ND: not determined.

At first, to evaluate possible toxicities, Balb-C mice were treated with different doses of calcitriol (Calcijex, Abbott Laboratórios do Brasil Ltda, São Paulo, Brazil), 1,2 or $3 \mu \mathrm{g} / \mathrm{Kg}$ (corresponding to $0.02,0.04$ or $0.06 \mu \mathrm{g} / \mathrm{mouse}$ ) by intraperitoneal route, weekly for 6 weeks. No significant toxicities were observed (data not shown), as previously described in human beings (Smith et al., 1999; Beer et al., 2001), and the chosen dose for the next procedures in nude mice was $0.06 \mu \mathrm{g} /$ mouse, which was associated with peak calcitriol concentrations around 1,800 pg/mL (approximately $4.3 \mathrm{nM}$ ) in a phase I clinical trial.

Female athymic nude mice (Foxn1nu) with approximately $20 \mathrm{~g}$ were provided by Centro de Bioterismo da Faculdade de Medicina da Universidade de São Paulo, São Paulo, Brazil. For orthotopic xenografting, a blade incision was made $1 \mathrm{~cm}$ lateral to the nipple on the pelvic region of the animal, under anesthesia with $0.01 \mathrm{~mL}$ xylazine $(20 \mathrm{mg} / \mathrm{mL}$, Vetbrands, Jacareí, SP, Brazil) and $0.04 \mathrm{~mL}$ Ketamine $(50 \mathrm{mg} / \mathrm{mL}$, Fort Dodge Laboratories, Fort Dodge, Iowa, USA), and following fat pad exposure, a tumor fragment (median diameter: 10mm) was implanted.

Surgical specimens were processed within two hours after tumor excision. One fragment of each tumor sample pre-xenografting was separated for histopathological analysis, as a control for the presence of invasive carcinoma.

In the beginning, each tumor sample (T3, T7) was implanted in four or more mice (time of implantation: week 0, zero). Afterwards, tumor samples were halved for implantation in only two mice. Animals were kept under pathogen free housing and mice weight as well as nodule largest dimension, using a caliper (called nodule, as histopathological analysis to verify malignant nature of the lesion was performed only on the $11^{\text {th }}$ week, after the end of treatment), were verified once a week.

After six weeks (week 6) mice were divided in two groups of treatment: one received intra-nodule injections of calcitriol $0.06 \mu \mathrm{g}$ (Calcijex, Abbott) and the other received vehicle, kindly prepared by Prof. Maria Aparecida Nicoletti (Department of Pharmacy, Faculdade de Ciências Farmacêuticas, Universidade de São Paulo, São Paulo, Brazil), based on the label of Calcijex, Abbott. Intra-nodule injections followed weekly, for 6 weeks (week 6 through week 11). On the day after the last calcitriol injection, 5-Bromo-2'-deoxyuridine 1mg (CAS 59-14-3, Calbiochem, Darmstadt, Germany) was administered by intraperitoneal route and after 2 hours, mice were euthanized. Blood samples were collected by cardiac puncture for determination of total serum calcium (Calcium reaction with arsenazo III in acidic medium, forming the calcium-arsenazo III blue color; absorbance of the reaction product was measured at wavelengths of 600 or $660 \mathrm{~nm}$ ). Nodules were frozen in liquid nitrogen or formalin fixed and paraffin embedded (FFPE) for subsequent analysis.

\subsection{Immunohistochemical analysis}

Sections of $3 \mu \mathrm{m}$ thickness were cut from paraffin blocks, and after antigen retrieval using pressure cooking in $10 \mathrm{mM}$ citrate buffer at $\mathrm{pH}$ 6.0. Immunohistochemistry reactions were performed using antibodies against Ki67 (Dako, Glostrup, Denmark; clone MIB-1, DAKO 7240, dilution 1:200); BrdU (Neomarkers, Fremont, CA, USA; clone Bu20a,1848-P, dilution 1:1000); BCL2 (Dako M0887, clone 124, dilution 1:500); p27 ${ }^{\text {Kip1 }}$ (Dako M7203, clone Sx53G8, dilution 1:1000); Vitamin D receptor (Millipore, Temecula, CA, USA; clone 9A7, Millipore 04-1526, dilution 1:30), followed by detection through Lab Vision ${ }^{\mathrm{TM}}$ UltraVision ${ }^{\mathrm{TM}}$ LP Detection System: HRP Polymer/DAB Plus Chromogen (visualized using 3.3'diaminobenzedine tetrahydrochloride (DAB, D-5637, Sigma, St. Louis, MO, USA). Sections were counterstained with Harris hematoxylin and coverslipped. Immunohistochemistry reactions were also performed in the absense of the $1^{\text {st }}$ antibody, as a negative 
control of the reaction. Staining of carcinoma cells was scored under light microscope by a medical pathologist (RAB) and immuno expression analysis are presented as percentage of positivity. Images were acquired on Nikon ACT-1 Software using 40X objective.

\subsection{RNA extraction and real time RT-PCR}

Fragments obtained from tumorgrafts were pulverized (Bio-Pulverizer ${ }^{\mathrm{TM}}$ BioSpec Products Inc., Oklahoma, USA) under liquid nitrogen and total RNA was isolated using RNeasy kit (Qiagen, Valencia, CA, USA), according to the manufacturer's protocol.

At first, cDNA was synthesized from 0.2-0.5 $\mu \mathrm{g}$ RNA from tumor samples or HB4A mammary epithelial cell line (donated by Drs. Mike O'Hare and Alan Mackay, Ludwig Institute for Cancer Research, London, UK). Reverse transcription was performed with random primers (Promega Corporation, Madison, USA,) and Superscript III (Invitrogen Corporation, Carlsbad, CA, USA). Quantitative PCR was carried out with $\mathrm{SYBR}{ }^{\circledR}$ Green PCR Power MasterMix (Life technologies, Carlsbad, CA, USA) and specific primers to the target genes or to GAPDH, which was used as an internal reference, in an Applied Biosystems 7900HT Fast Real-Time PCR System (Applied Biosystems, Foster City, CA, USA), using the following program: $10 \mathrm{~min}$ at $95^{\circ} \mathrm{C}$ for initial denaturation, followed by 40 cycles at $95^{\circ} \mathrm{C}$ for $15 \mathrm{~s}$ and $60^{\circ} \mathrm{C}$ for $1 \mathrm{~min}$. Values from duplicate reactions were then averaged. Relative gene expression on the tumor sample was then normalized to the value of HB4A cells, using the $2^{-\triangle \Delta \mathrm{CT}}$ methodology.

\subsection{Statistical analysis}

Non-parametric tests (Mann Whithey U test for unrelated samples and Wilcoxon signed ranks test or Friedman test for related samples) were used to evaluate the significance level of the difference. A two-tailed $p$ value $\leq 0.05$ was considered significant. Analysis was undertaken using SPSS software (Chicago, IL, USA).

\section{Results}

\subsection{Establishment of tumorgrafts using fresh breast cancer slices}

Mice were implanted with fragments from 12 different tumor samples and on the sixth week, no palpable nodules were detected in mice implanted with T9, T10, T17, T19, which were not further evaluated. On the remaining 21 mice, xenografted with T3 (4 mice), T7 (5 mice), T8, T11, T12, T13, T14, T16 (2 mice each), intra-nodule weekly injections of calcitriol $0.06 \mu \mathrm{g}$ or vehicle, were initiated and maintained for the next weeks (week 6 through week 11). A nodule that developed in mice implanted with T7 and treated with vehicle or calcitriol is exemplified in Figure 1.

Mice weight presented neither differences between vehicle and calcitriol treated animals at the end of the experiment (week 11) nor between the $6^{\text {th }}$ week and the $11^{\text {th }}$ week, comparing each treatment group separately (Figure 2A). Serum calcium, evaluated 24 hours after the last intra-nodule injection, was higher in calcitriol treated animals than in vehicle treated mice $(8.2 \pm 1.7$ vs $6.4 \pm 1.1 \mathrm{mg} / \mathrm{dL}$,

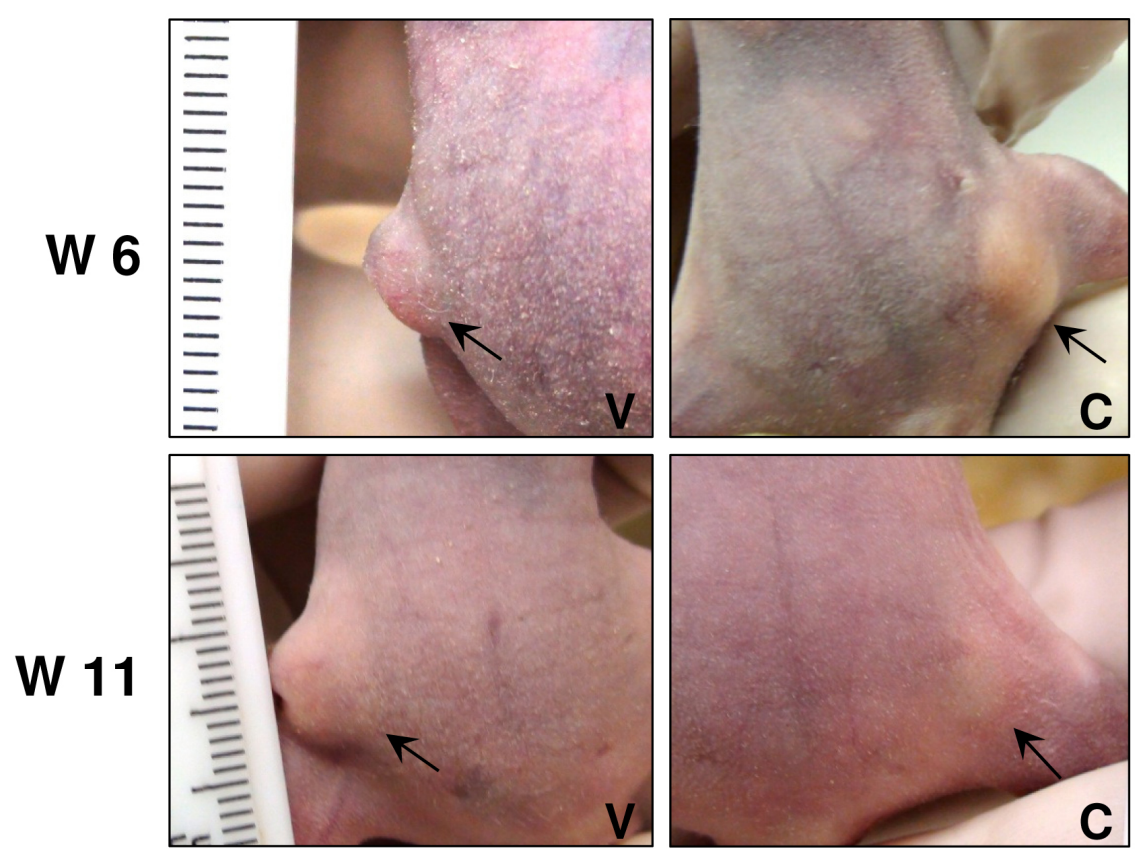

Figure 1. Nodules detected in mice xenografted with T7 breast cancer sample at the beginning ( $6^{\text {th }}$ week, W6) and ending of treatment $\left(11^{\text {th }}\right.$ week, W11) with vehicle or calcitriol. Histopathology evaluation of these nodules revealed invasive carcinoma. 

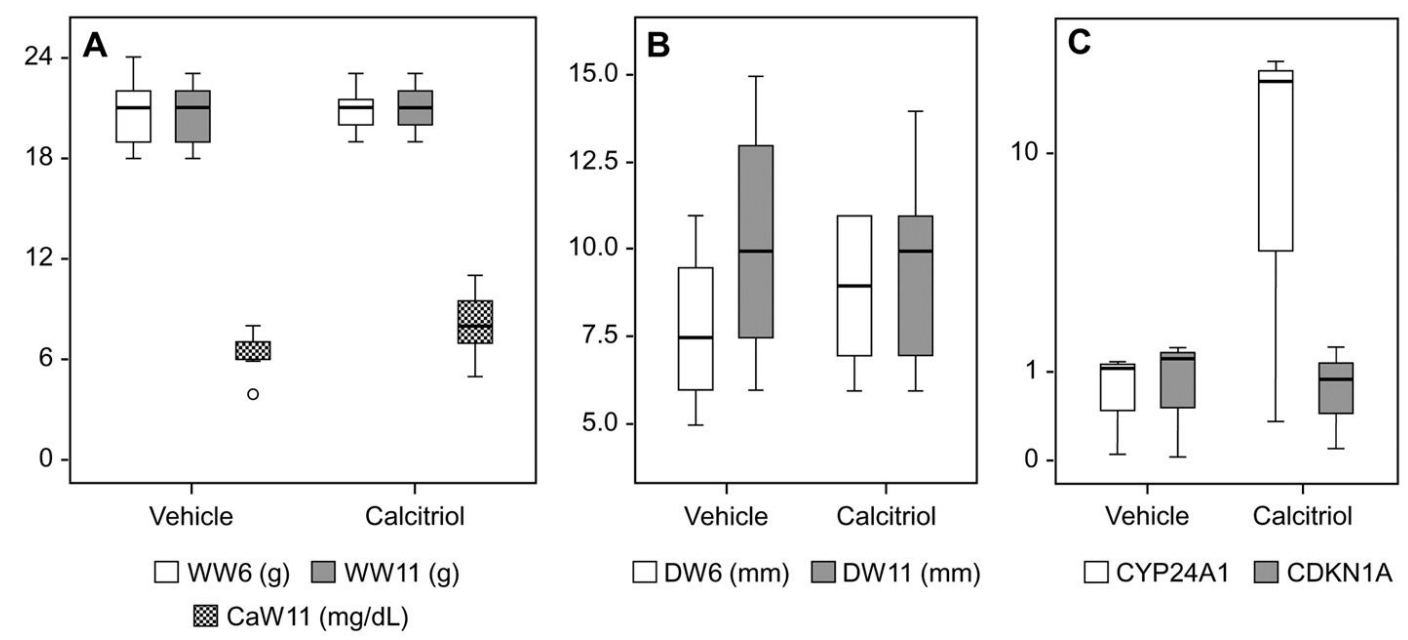

Figure 2. (A) Weight and calcemia in mice xenografted with 8 different tumor samples. Tumor samples from 8 patients (T3, T7, T8, T11, T12, T13, T14, T16) were grafted in 21 mice (each tumor sample was xenografted in two mice, except for samples T3, xenografted in four mice, two treated with vehicle and two with calcitriol and T7, xenografted in five mice, two treated with vehicle and three with calcitriol). After 6 weeks (W6, beginning of treatment) mice were treated with intra-nodule injections of vehicle $(\mathrm{n}=10)$ or calcitriol $0.06 \mu \mathrm{g}(\mathrm{n}=11)$ for 6 weeks (week 11, W11, end of treatment). No differences in mice weight (W in grams, g) were detected: a) at the end of treatment (weight at week 11, WW11 vehicle vs calcitriol: $\mathrm{p}=0.685$, Mann Whitney test); $\mathrm{b}$ ) at the beginning and ending of treatment in both vehicle treated (weight at week 6, WW6 vs WW11: $\mathrm{n}=10, \mathrm{p}=0.773$; Wilcoxon test) and calcitriol treated (WW6 vs WW11: $\mathrm{n}=11$, $\mathrm{p}=0.739$; Wilcoxon test) animals. Calcemia (Ca) was determined one day after the last intra-tumoral injection (Ca W11) and was higher in calcitriol than in vehicle treated animals ( $\mathrm{p}=0.014$, Mann Whitney $U$ test). (B) Tumorgraft dimension in nine mice that developed tumorgrafts T7, T11 and T16. Mice xenografted with T7 (5 animals, 3 treated with calcitriol and 2 with vehicle), T11 and T16 (1 pair each, treated with calcitriol or vehicle) developed nodules which were measured in the $6^{\text {th }}$ week after implantation (DW6, dimension week 6, beginning of treatment with intra-tumoral injection with vehicle or calcitriol) and $11^{\text {th }}$ week (1 day after the last injection, DW11). Histopathological analysis revealed malignant lesion at the end of treatment. No differences were observed in tumorgraft dimension evaluated at the beginning and ending of treatment (Vehicle DW6 vs DW11: $\mathrm{p}=0.102$; Calcitriol DW6 vs DW11: $\mathrm{p}=0.581$, Wilcoxon test). (C) CYP24A1 and CDKN1A mRNA relative expression in tumorgrafts (T7, T11, T16) treated with vehicle or calcitriol. No statistically significant differences between groups (vehicle vs calcitriol; $\mathrm{n}=3$ : T7, T11, T16) were observed. (CYP24A1: $\mathrm{p}=0.109$; CDKN1A: $\mathrm{p}=1,000$; Wilcoxon signed ranks test). $\mathrm{Y}$ axis presented in $\log$ scale.

respectively; Figure 2A). No hypercaelcemia was detected (Suckow et al., 2001).

At the end of the experiment ( $11^{\text {th }}$ week), all nodules were dissected and submitted to histopathological analysis. Four samples of T3 (from two calcitriol treated and two vehicle treated mice) revealed stroma or necrosis. Each pair of samples originated from T8, T12, T13 and T14, revealed only a very small area of invasive carcinoma, preventing further evaluations, through immunohistochemistry reactions.

Histopathological analysis from nodules collected from nine mice xenografted with three different tumor samples [T7 $(n=5$; two treated with vehicle and three with calcitriol), T11 $(\mathrm{n}=2)$ and T16 $(\mathrm{n}=2)$ ] revealed invasive carcinoma, occupying at least $50 \%$ of the area, except for T11 treated with calcitriol, where only carcinoma in situ or normal mammary duct were identified. From now on, results will focus only on these mice, which developed evaluable malignant lesions (designated tumorgrafts). In this subgroup of mice no differences in tumor dimension were detected, comparing the beginning (W6, week 6) and ending of treatment (W11, week 11) in both vehicle and calcitriol treated animals (Figure 2B). These samples were then analyzed for proliferation and apoptosis markers and VDR target genes.

\subsection{VDR expression}

VDR expression was evaluated in pre-xenograft samples by immunohistochemistry reactions, using a specific antibody against the receptor. VDR expression was observed in all three pre-xenograft samples, as a faint, mainly cytoplasmic and sporadic nuclear staining of malignant cells (Figure 3).

\subsection{Expression of proliferation and apoptosis markers in tumor samples and tumorgrafts}

Tumor samples, obtained from patients, and/or tumorgrafts, collected from mice, were analyzed for proliferation, through Ki67 expression (Figure 4), BrdU incorporation (tumorgrafts only; Figure 5) and CDKN1B expression (p27 KIP1) (Figure 6) as well as for apoptosis, through BCL2 expression (Figure 7), in malignant cells. 


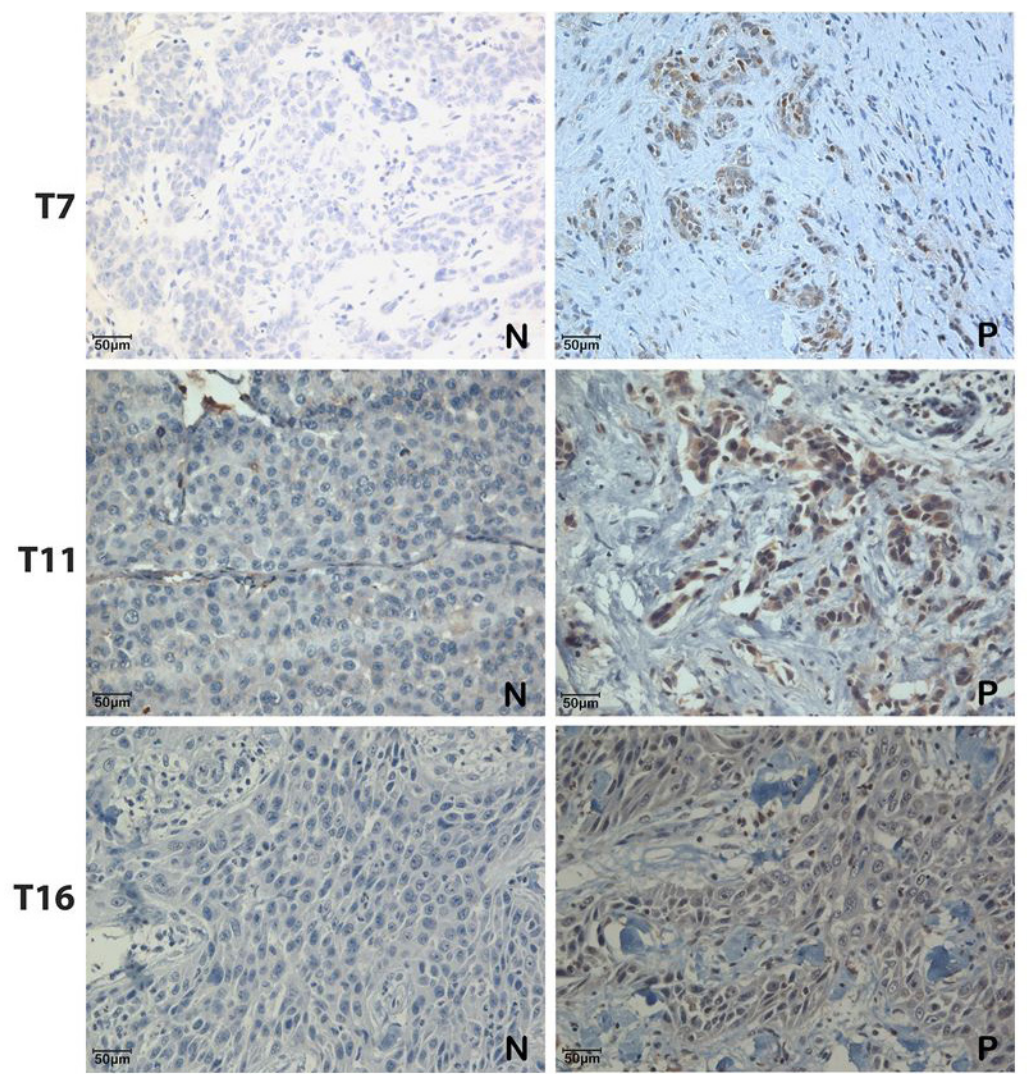

Figure 3. VDR expression in tumor samples T7, T11 and T16 pre-xenografting. VDR expression appears as a faint cytoplasmic and sporadic nuclear staining of malignant cells. $(\mathrm{N})$ negative reaction without first antibody; (P): positive reaction with anti VDR antibody.

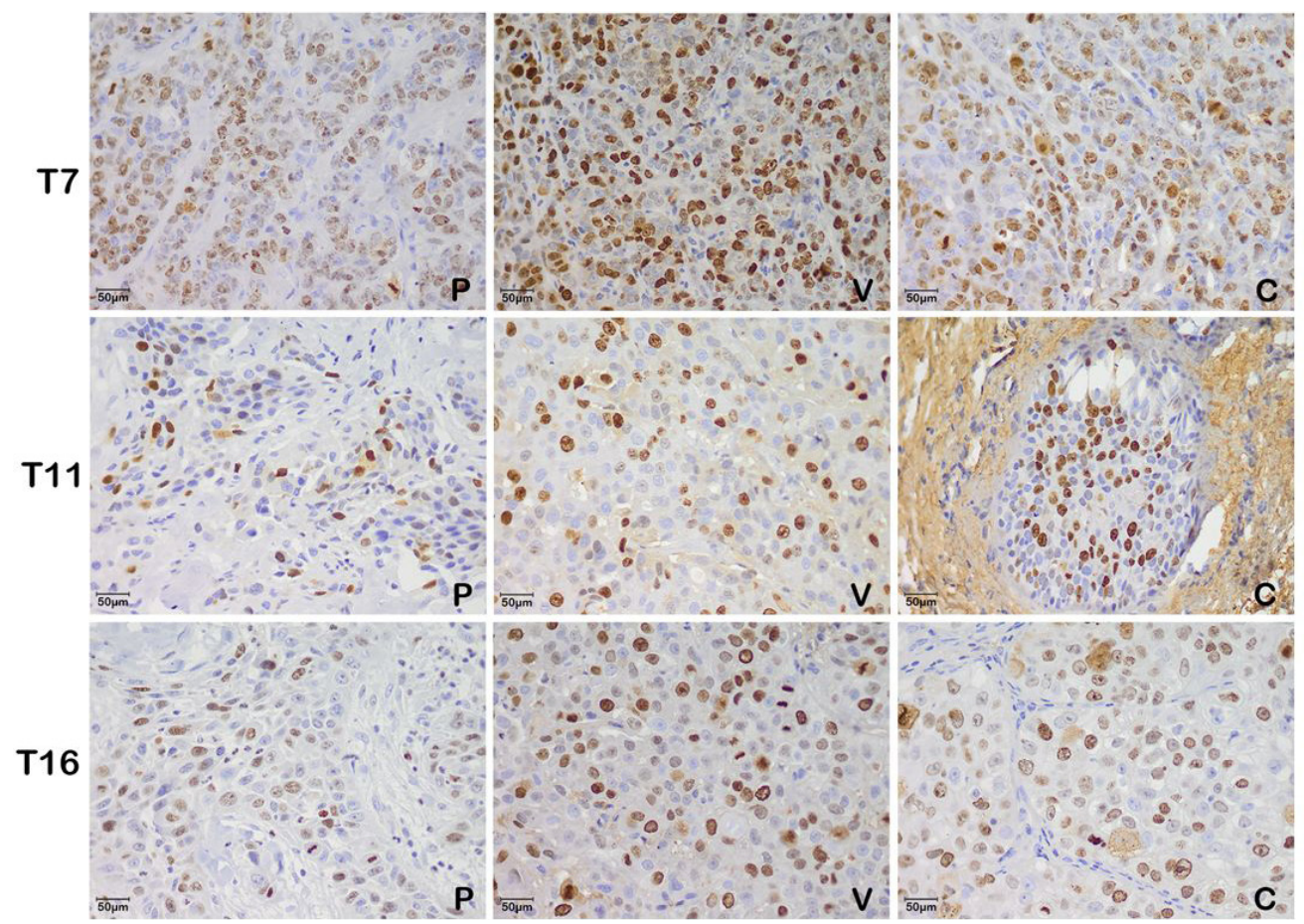

Figure 4. Ki67 expression in tumor samples T7, T11 and T16 pre-xenografting (P) and tumorgrafts obtained from mice after vehicle (V) or calcitriol (C) treatment for 6 weeks. Nuclear staining was detected in malignant cells. 


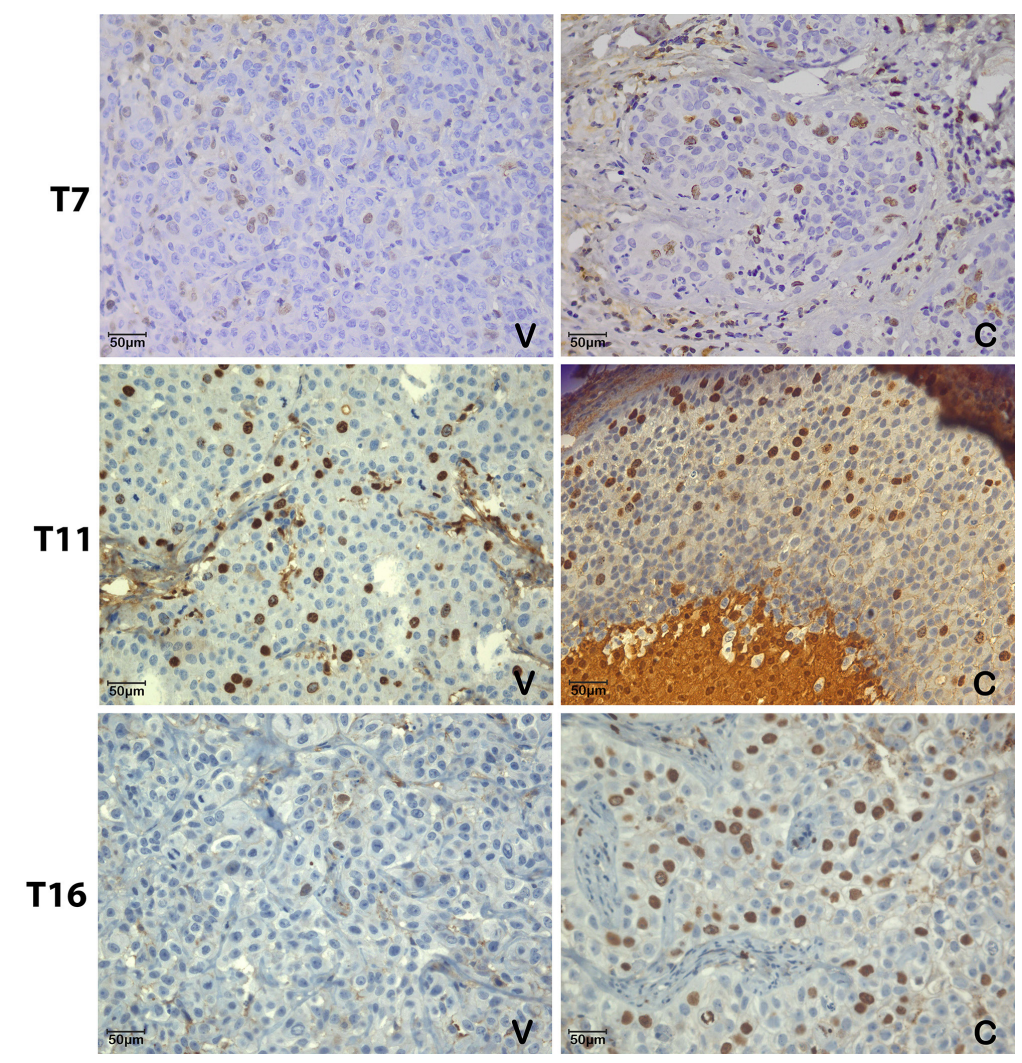

Figure 5. BrdU incorporation in T7, T11 and T16 tumorgrafts obtained from mice after vehicle (V) or calcitriol (C) treatment for 6 weeks. Tumorgrafts were collected 24 hours after the last intra-tumoral injection of calcitriol and two hours after BrdU intraperitoneal injection, and analyzed by immunohistochemistry reactions.

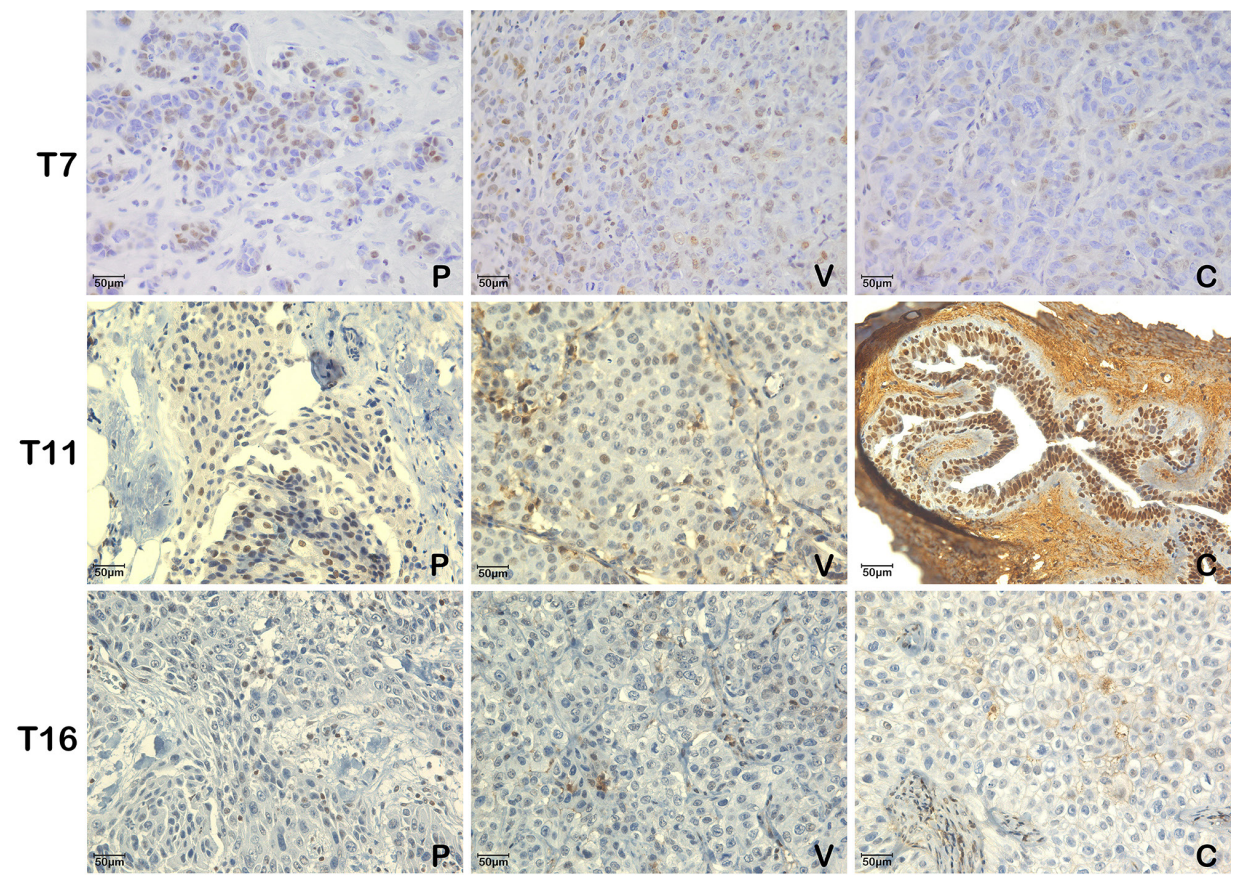

Figure 6. CDKN1B (p27 ${ }^{\mathrm{KIP} 1}$ ) expression in tumor samples T7, T11 and T16 pre-xenografting $(\mathrm{P})$ and tumorgrafts obtained from mice after vehicle $(\mathrm{V})$ or calcitriol $(\mathrm{C})$ treatment. A faint nuclear staining in malignant cells was detected, except for T16, where only scant lymphocytes were stained. A strong staining was detected in a mammary duct from tumorgraft $\mathrm{T} 11$ treated with calcitriol. 


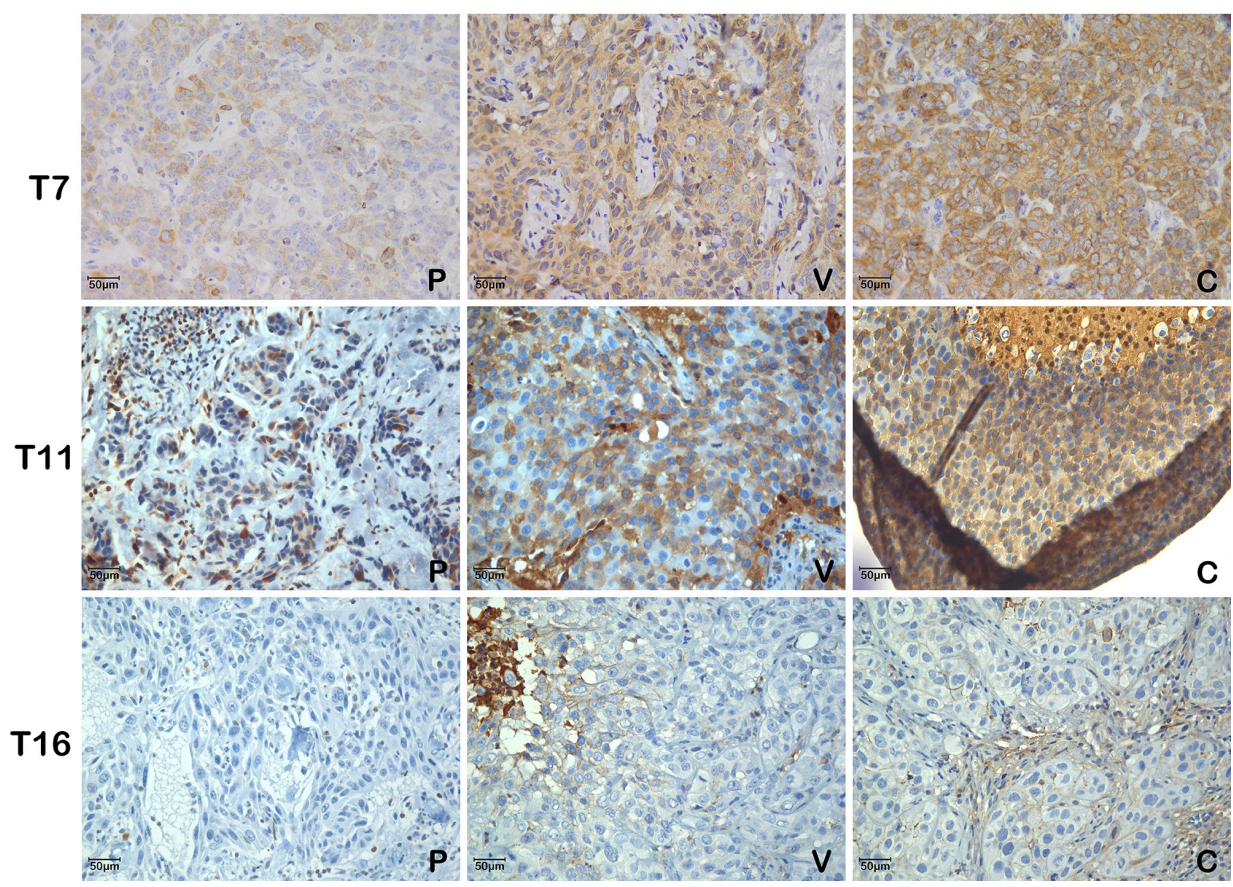

Figure 7. BCL2 expression in tumor samples T7, T11 and T16 pre-xenografting $(\mathrm{P})$ and tumorgrafts obtained from mice after vehicle (V) or calcitriol (C) treatment for 6 weeks. BCL2 expression was detected as a faint diffuse cytoplasmic staining in malignant cells.

All three tumor samples (T7, T11, T16), obtained from patients, were highly proliferative (Ki67 expression detected in at least $20 \%$ of malignant cells in control samples pre-xenografting). A high proliferative index was also detected in both calcitriol and vehicle treated tumorgrafts, as at least $40 \%$ of the malignant cells expressed Ki67 (Figure 4). In addition, BrdU incorporation was observed in more than $10 \%$ of the malignant cells from tumorgrafts, except for its absence in tumorgraft T16 vehicle treated, where a discrepancy between BrdU positive and Ki67 expressing cells was detected (Figures 4, 5). Hence, all tumorgrafts samples, irrespective of treatment, presented a high proliferation index.

CDKN1B expression was detected as a faint positive nuclear staining in $10-20 \%$ of malignant cells from pre xenografting $\mathrm{T} 7$ and $\mathrm{T} 11$, as well as $\mathrm{T} 11$ vehicle treated samples. In T7 tumorgrafts, no differences in CDKN1B staining were observed between vehicle and calcitriol treated samples. A stronger CDKN1B staining was detected in epithelial cells of a mammary duct from T11 tumorgraft exposed to calcitriol, however, malignant disease was not present in this slide and no more FFPE sample was available for additional processing. On the other hand, CDKN1B expression, except for its presence in scant lymphocytes, was neither detected in T16 pre xenografting tumor sample nor in T16 tumorgrafts (Figure 6).

BCL2 expression was detected as a faint diffuse cytoplasmic staining in malignant cells (Figure 7). All T7 samples (pre xenograft and derived tumorgrafts) presented a high percentage (>70\%) and all T16 samples presented a low percentage of BCL2 positive cells $(<5 \%)$. T11 pre xenograft sample, except for lymphocytes, was negative for BCL2 expression; on the other hand, T11 derived tumorgrafts presented more than $50 \%$ of BCL2 positive cells.

In these three tumorgrafts, no differences in BrdU incorporation, Ki67 and CDKN1B expression between vehicle and calcitriol treated samples, (Figures 4-6) that could characterize an anti proliferative effect of vitamin $\mathrm{D}$, were observed. In addition neither differences on the expression of apoptosis markers, as BCL2 (Figure 7), were detected between vehicle and calcitriol treated tumorgrafts.

\subsection{Expression of vitamin D target genes in tumorgrafts}

Expression of CYP24A1 and CDKN1A was evaluated in tumorgrafts T7, T11, T16 treated with vehicle and calcitriol. Although a statistically significant induction of CYP24A1 mRNA expression in calcitriol treated samples could not be detected (Figure 2C), comparing each paired sample individually, a higher CYP24A1 expression was observed in each one of them, after exposure to the hormone (T7: 10.4; T11: 18.5 and T16: 17 fold induction). No difference between groups was detected for the expression of CDKN1A mRNA (Figure 2C).

\section{Discussion}

In the present work, freshly collected breast cancer samples were orthotopically xenotransplanted in nude mice. This preclinical model enables direct analysis of patient derived tumor samples (Zhang et al., 2013), as well 
as concomitant evaluation of hormone adverse effects. Although immunocompromised mice have been used to evaluate hormone actions in breast cancer xenografts, established from cell lineages (Cruz et al., 2001), this is the first effort to evaluate calcitriol effects in tumorgrafts.

Among 12 samples that were xenografted in Foxn1nu mice, only three, with aggressive characteristics (highly proliferative, histological grade 3 or HER2 positive) developed into tumorgrafts, with enough malignant tissue available for further studies. However, some mice xenotransplanted with tumor samples with similar aggressive features (triple negative or with a high proliferation index), originated palpable nodules which upon histopathological analysis, revealed absence or insufficient malignant tissue, preventing further analysis. A comparable success rate was already reported in non obese diabetic severe combined immunodeficiency mice (NOD-SCID), engrafted with luminal, triple negative or HER2 breast cancer subtypes (DeRose et al., 2011). Some authors, however reported higher engraftment rate after implanting nude mice with sarcomas or prostate cancer samples. In the first case, very aggressive sarcoma samples were chosen (tumors already resistant to chemotherapy) and in the second case, a longer time for prostate tumor development was used (Stebbing et al., 2014; Saar et al., 2015).

In our study, VDR expression was detected in all three samples (T7, T11 and T16), and in accordance VDR expression was previously demonstrated in a high percentage of breast cancer samples (Lyra et al., 2006; Bortman et al., 2002; Ditsch et al., 2012). In the present xenografts CYP24A1 mRNA expression was increased by 10 to 18 fold upon calcitriol treatment, demonstrating induction of the genomic vitamin D pathway. However, mRNA expression of another potential target gene of vitamin $\mathrm{D}, \mathrm{CDKN} 1 \mathrm{~A}$ (that codes for $\mathrm{p} 21^{\mathrm{WAF} 1 / \mathrm{CIP} 1}$, an inhibitor of cell cycle), was not altered by calcitriol treatment (Saramaki et al., 2006).

Previous authors have reported that tumorgrafts in the first passage maintain the original tumor characteristics (DeRose et al., 2011). In accordance no main differences in proliferation and apoptosis immunohistochemistry markers were found between prexenografting and tumorgraft vehicle treated samples in the present work.

In these turmografts, vitamin D did not clearly exert antiproliferative effects. Ki67 expression, which was one of the proliferation markers evaluated, was already shown to reflect tumor response to endocrine therapy (Dowsett et al., 2005). One possibility is that the aggressive subtypes that originated tumorgrafts, consisting of highly proliferative or ER negative tumors might constitute refractory samples to calcitriol antiproliferative effects. Tumorgrafts T7 and T16 were originated from luminal B highly proliferative samples with some differential characteristics: CDKN1B and BCL2 expression were both detected in $\mathrm{T} 7$ prexenografting sample, in contrast with T16 prexenografting sample, where neither CDKN1B nor BCL2 expression were detected. In T7 tumorgrafts, neither proliferation (evaluated through Ki67 and CDKN1B expression, as well as BrdU incorporation), nor apoptosis, (evaluated through BCL2 immunoexpression), were influenced by calcitriol administration. In agreement, in T16 tumorgrafts, expression of Ki67, CDKN1B and BCL2 were similar upon vehicle or calcitriol treatment.

T11 tumorgraft was derived from a HER2 positive highly proliferative tumor. In vehicle treated tumorgraft a high proliferation index was detected, however in calcitriol treated mice only carcinoma in situ or normal mammary ducts were detected. This finding might be a consequence of xenografting only in situ carcinoma in one of the mice or from growth inhibition of the invasive component, upon calcitriol treatment. Before tumor xenografting, all samples were checked for the presence of invasive disease through histopathological analysis, however, we cannot guarantee that the same amount of invasive component was present in each implanted fragment. In calcitriol treated T11 tumorgrafts, active proliferation was still detected through Ki67 expression and BrdU incorporation in malignant cells from the in situ carcinoma. In contrast, CDKN1B expression was detected in normal mammary duct cells, indicating that growth inhibition was taking place in this structure.

In this study, calcitriol dose was based on a pharmacokinetic modeling from a phase I study of intermittent pulse calcitriol, which showed that weekly doses up to $2.8 \mu \mathrm{g} / \mathrm{kg}$ PO produced peak calcitriol serum concentration around $4.3 \mathrm{nM}$ (Beer et al., 2001). We applied calcitriol directly into the tumor, to attain a high local concentration, without major systemic side effects. This objective was met as neither hypercalcemia nor differences in animal weight, were observed in vehicle and calcitriol treated mice.

It was previously shown that vitamin D daily supplementation in the diet, as well as calcitriol intraperitoneal administration (IP) three times a week $(0.05 \mu \mathrm{g} / \mathrm{mouse})$ or daily $(0.5 \mu \mathrm{g} / \mathrm{kg})$ can inhibit growth of MCF7 (breast cancer cells) or SKHEP (liver cancer cells) xenograft growth in nude mice (Pourgholami et al., 2000; Swami et al., 2012). In human beings, it was also reported that after subcutaneous administration, calcitriol plasma concentrations reach and maintain peak levels between 2 and 8 hours, returning to the normal physiological range after 48 hours (Smith et al., 1999; Beer et al., 2001). One possible explanation for our negative results is that a minimum threshold concentration of vitamin D should be maintained, in order to achieve antitumoral effects, as in the above studies calcitriol was more frequently administered than in our work. On the other hand, in our model of weekly intra-tumoral calcitriol administration, a more pronounced induction of CYP24A1 expression (at least 10 fold) was observed, as compared with another study, where a more frequent schedule of calcitriol administration of MCF7 xenografts was employed (Swami et al., 2012). CYP24A1 codes for an enzyme that hydroxylates $25(\mathrm{OH}) \mathrm{D}_{3}$ or $1,25(\mathrm{OH})_{2} \mathrm{D}_{3}$ to $24,25(\mathrm{OH})_{2} \mathrm{D}_{3}$ or $1,24,25(\mathrm{OH})_{3} \mathrm{D}_{3}$, less active forms of the hormone, and in that sense, might function as a double-edged sword. A possibility is that increased CYP24A1 tumorgraft expression (resulting in decreased $1,25(\mathrm{OH})_{2} \mathrm{D}_{3}$ levels) 
in conjunction with relatively prolonged calcitriol nadir levels, (following longer administration intervals), might have precluded vitamin D antiproliferative effects.

Strengths of this work are the evaluation of tumorgrafts, which more closely resembles breast cancer heterogeneity and its microenvironment as well as exposure to potentially meaningful therapeutic concentrations of calcitriol, through intra-tumoral injections. On the other hand, a weakness is the small number of samples analyzed, due to a low tumorgraft take rate, originated from different tumor subtypes, which precludes generalization of these results.

In summary, this is the first evaluation of calcitriol effects in breast cancer tumorgrafts. In this model, original tumor characteristics were preserved, however, even though vitamin D genomic pathway was induced, calcitriol antiproliferative effects were not observed. In these highly proliferative samples, CYP24A1 mRNA strong induction might have precluded vitamin D antitumoral effects. This data indicates that tumorgrafts seem a promising model to evaluate other regimens of calcitriol administration.

\section{Acknowledgements}

This work was supported by Fundação de Amparo à Pesquisa do Estado de São Paulo (FAPESP) grant No 11/09103-1, Coordenação de Aperfeiçoamento de Pessoal de Nível Superior (CAPES) - Project No 029/2012 and CNPQ. The authors are very grateful to Prof. Maria Aparecida Nicoletti, for preparing the vehicle and to Mrs. Cristina Piñeiro Grandal, for editing the figures.

\section{References}

ABBAS, S., LINSEISEN, J., SLANGER, T., KROPP, S., MUTSCHELKNAUSS, E.J., FLESCH-JANYS, D. and CHANGCLAUDE, J., 2008. Serum 25-hydroxyvitamin D and risk of post-menopausal breast cancer--results of a large case-control study. Carcinogenesis, vol. 29, no. 1, pp. 93-99. PMid:17974532. http://dx.doi.org/10.1093/carcin/bgm240.

ALBERTSON, D.G., YLSTRA, B., SEGRAVES, R., COLLINS, C., DAIRKEE, S.H., KOWBEL, D., KUO, W.L., GRAY, J.W. and PINKEL, D., 2000. Quantitative mapping of amplicon structure by array CGH identifies CYP24 as a candidate oncogene. Nature Genetics, vol. 25, no. 2, pp. 144-146. PMid:10835626. http:// dx.doi.org/10.1038/75985.

BEER, T.M., MUNAR, M. and HENNER, W.D., 2001. A Phase I trial of pulse calcitriol in patients with refractory malignancies: pulse dosing permits substantial dose escalation. Cancer, vol. 91, no. 12, pp. 2431-2439. PMid:11413535. http://dx.doi.org/10.1002/10970142(20010615)91:12<2431::AID-CNCR1278>3.0.CO;2-3.

BERTONE-JOHNSON, E.R., CHEN, W.Y., HOLICK, M.F., HOLLIS, B.W., COLDITZ, G.A., WILLETT, W.C. and HANKINSON, S.E., 2005. Plasma 25-hydroxyvitamin D and 1,25-dihydroxyvitamin D and risk of breast cancer. Cancer Epidemiology, Biomarkers \& Prevention, vol. 14, no. 8, pp. 1991-1997. PMid:16103450. http://dx.doi.org/10.1158/1055-9965.EPI-04-0722.

BORTMAN, P., FOLGUEIRA, M.A., KATAYAMA, M.L., SNITCOVSKY, I.M. and BRENTANI, M.M., 2002. Antiproliferative effects of 1,25-dihydroxyvitamin D3 on breast cells: a minireview.
Brazilian Journal of Medical and Biological Research, vol. 35, no. 1, pp. 1-9. PMid:11743608. http://dx.doi.org/10.1590/S0100879X2002000100001

BOWER, M., COLSTON, K.W., STEIN, R.C., HEDLEY, A., GAZET, J.C., FORD, H.T. and COMBES, R.C., 1991. Topical calcipotriol treatment in advanced breast cancer. Lancet, vol. 337, no. 8743, pp. 701-702. PMid:1672178. http://dx.doi. org/10.1016/0140-6736(91)90280-3.

CAMPOS, L.T., BRENTANI, H., ROELA, R.A., KATAYAMA, M.L., LIMA, L., ROLIM, C.F., MILANI, C., FOLGUEIRA, M.A. and BRENTANI, M.M., 2013. Differences in transcriptional effects of $1 \alpha, 25$ dihydroxyvitamin D3 on fibroblasts associated to breast carcinomas and from paired normal breast tissues. The Journal of Steroid Biochemistry and Molecular Biology, vol. 133, pp. 12-24. PMid:22939885. http://dx.doi.org/10.1016/j.jsbmb.2012.08.002.

CRUZ, L.M.S., FERREIRA, J.C.V. and MELLO, M.L.S., 2001. Apoptotic ratios and mitotic abnormalities in 17- $\beta$-estradioltransformed human breast epithelial MCF-10F cells. Brazilian Journal of Biology $=$ Revista Brasileira de Biologia, vol. 71, no. 2, pp. 1-4. http://dx.doi.org/10.159/S1519-69842011000300019. PMid:21755167.

DEROSE, Y.S., WANG, G., LIN, Y.C., BERNARD, P.S., BUYS, S.S., EBBERT, M.T., FACTOR, R., MATSEN, C., MILASH, B.A., NELSON, E., NEUMAYER, L., RANDALL, R.L., STIJLEMAN, I.J., WELM, B.E. and WELM, A.L., 2011. Tumor grafts derived from women with breast cancer authentically reflect tumor pathology, growth, metastasis and disease outcomes. Nature Medicine, vol. 17, no. 11, pp. 1514-1520. PMid:22019887. http:// dx.doi.org/10.1038/nm.2454.

DITSCH, N., MAYR, D., LENHARD, M., STRAUSS, C., VODERMAIER, A., GALLWAS, J., STOECKL, D., GRAESER, M., WEISSENBACHER, T., FRIESE, K. and JESCHKE, U., 2012. Correlation of thyroid hormone, retinoid $X$, peroxisome proliferator-activated, vitamin D and oestrogen/progesterone receptors in breast carcinoma. Oncology Letters, vol. 4, no. 4, pp. 665-671. PMid:23205080.

DOWSETT, M., EBBS, S.R., DIXON, J.M., SKENE, A., GRIFFITH, C., BOEDDINGHAUS, I., SALTER, J., DETRE, S., HILLS, M., ASHLEY, S., FRANCIS, S., WALSH, G. and SMITH, I.E., 2005. Biomarker changes during neoadjuvant anastrozole, tamoxifen, or the combination: influence of hormonal status and HER-2 in breast cancer: a study from the IMPACT trialists. Journal of Clinical Oncology, vol. 23, no. 11, pp. 2477-2492. PMid:15767642. http://dx.doi.org/10.1200/JCO.2005.07.559.

GANDINI, S., BONIOL, M., HAUKKA, J., BYRNES, G., COX, B., SNEYD, M.J., MULLIE, P. and AUTIER, P., 2011. Metaanalysis of observational studies of serum 25-hydroxyvitamin D levels and colorectal, breast and prostate cancer and colorectal adenoma. International Journal of Cancer, vol. 128, no. 6, pp. 1414-1424. PMid:20473927. http://dx.doi.org/10.1002/ijc.25439.

GARLAND, C.F., GARLAND, F.C., GORHAM, E.D., LIPKIN, M., NEWMARK, H., MOHR, S.B. and HOLICK, M.F., 2006. The role of vitamin D in cancer prevention. American Journal of Public Health, vol. 96, no. 2, pp. 252-261. PMid:16380576. http://dx.doi.org/10.2105/AJPH.2004.045260.

GOODWIN, P.J., ENNIS, M., PRITCHARD, K.I., KOO, J. and HOOD, N., 2009. Prognostic effects of 25-hydroxyvitamin D levels in early breast cancer. Journal of Clinical Oncology, vol. 27, no. 23, pp. 3757-3763. PMid:19451439. http://dx.doi. org/10.1200/JCO.2008.20.0725. 
HIATT, R.A., KRIEGER, N., LOBAUGH, B., DREZNER, M.K., VOGELMAN, J.H. and ORENTREICH, N., 1998. Prediagnostic serum Vitamin D and breast cancer. Journal of the National Cancer Institute, vol. 90, no. 6, pp. 461-463. PMid:9521171. http://dx.doi.org/10.1093/jnci/90.6.461.

JANOWSKY, E.C., LESTER, G.E., WEINBERG, C.R., MILLIKAN, R.C., SCHILDKRAUT, J.M., GARRETT, P.A. and HULKA, B.S., 1999. Association between low levels of 1,25-dihydroxyvitamin D and breast cancer risk. Public Health Nutrition, vol. 2, no. 3, pp. 283-291. PMid:10512563. http:// dx.doi.org/10.1017/S1368980099000385.

KATAYAMA, M.L.H., PASINI, F.S., FOLGUEIRA, M.A.A.K., SNITCOVSKY, I.M.L. and BRENTANI, M.M., 2003. Molecular targets of 1,25(OH)2D3 in HC11 normal mouse mammary cell line. The Journal of Steroid Biochemistry and Molecular Biology, vol. 84, no. 1, pp. 57-69. PMid:12648525. http://dx.doi.org/10.1016/ S0960-0760(03)00004-9.

KNOWER, K.C., CHAND, A.L., ERIKSSON, N., TAKAGI, K., MIKI, Y., SASANO, H., VISVADER, J.E., LINDEMAN, G.J., FUNDER, J.W., FULLER, P.J., SIMPSON, E.R., TILLEY, W.D., LEEDMAN, P.J., GRAHAM, J., MUSCAT, G.E., CLARKE, C.L. and CLYNE, C.D., 2013. Distinct nuclear receptor expression in stroma adjacent to breast tumors. Breast Cancer Research and Treatment, vol. 142, no. 1, pp. 211-223. PMid:24122391. http:// dx.doi.org/10.1007/s10549-013-2716-6.

LOHMANN, A.E., CHAPMAN, J.A., BURNELL, M.J., LEVINE, M.N., TSVETKOVA, E., PRITCHARD, K.I., GELMON, K.A., O'BRIEN, P., HAN, L., RUGO, H.S., ALBAIN, K.S., PEREZ, E.A., VANDENBERG, T.A., CHALCHAL, H.I., SAWHNEY, R.P., SHEPHERD, L.E. and GOODWIN, P.J., 2015. Prognostic associations of 25 hydroxy vitamin D in NCIC CTG MA.21, a phase III adjuvant randomized clinical trial of three chemotherapy regimens in high-risk breast cancer. Breast Cancer Research and Treatment, vol. 150, no. 3, pp. 605-611. PMid:25833209. http:// dx.doi.org/10.1007/s10549-015-3355-X.

LOPES, N., SOUSA, B., MARTINS, D., GOMES, M., VIEIRA, D., VERONESE, L.A., MILANEZI, F., PAREDES, J., COSTA, J.L. and SCHMITT, F., 2010. Alterations in Vitamin D signalling and metabolic pathways in breast cancer pro andression: a study of VDR, CYP27B1 and CYP24A1 expression in benign and malignant breast lesions. BMC Cancer, vol. 10, pp. 483. PMid:20831823. http://dx.doi.org/10.1186/1471-2407-10-483.

LYRA, E.C., DA SILVA, I.A., KATAYAMA, M.L., BRENTANI, M.M., NONOGAKI, S., GOES, J.C. and FOLGUEIRA, M.A., 2006. 25(OH)D3 and 1,25(OH)2D3 serum concentration and breast tissue expression of 1alpha-hydroxylase, 24-hydroxylase and Vitamin D receptor in women with and without breast cancer. The Journal of Steroid Biochemistry and Molecular Biology, vol. 100, no. 4-5, pp. 184-192. PMid:16828283. http://dx.doi. org/10.1016/j.jsbmb.2006.04.009.

MILANI, C., KATAYAMA, M.L., LYRA, E.C., WELSH, J., CAMPOS, L.T., BRENTANI, M.M., MACIEL, M.D.O.S., ROELA, R.A., VALLE, P.R., GÓES, J.C., NONOGAKI, S., TAMURA, R.E. and FOLGUEIRA, M.A., 2013. Transcriptional effects of 1,25 dihydroxyvitamin $\mathrm{D}(3)$ physiological and supraphysiological concentrations in breast cancer organotypic culture. BMC Cancer, vol. 13, no. 1, pp. 119. PMid:23497279. http:/ dx.doi.org/10.1186/1471-2407-13-119.

ORDÓÑEZ-MENA, J.M., SCHÖTTKER, B., FEDIRKO, V., JENAB, M., OLSEN, A., HALKJÆR, J., KAMPMAN, E., DE GROOT, L., JANSEN, E., BUENO-DE-MESQUITA, H.B., PEETERS, P.H., SIGANOS, G., WILSGAARD, T., PERNA, L.,
HOLLECZEK, B., PETTERSSON-KYMMER, U., ORFANOS, P., TRICHOPOULOU, A., BOFFETTA, P. and BRENNER, H., 2015. Pre-diagnostic vitamin D concentrations and cancer risks in older individuals: an analysis of cohorts participating in the CHANCES consortium. European Journal of Epidemiology, vol. 15, pp. 1-13. PMid:25977096.

POURGHOLAMI, M.H., AKHTER, J., LU, Y. and MORRIS, D.L., 2000. In vitro and in vivo inhibition of liver cancer cells by 1,25-dihydroxyvitamin D3. Cancer Letters, vol. 151, no. 1, pp. 97-102. PMid:10766428. http://dx.doi.org/10.1016/S03043835(99)00416-4.

SAAR, M., KÖRBEL, C., LINXWEILER, J., JUNG, V., KAMRADT, J., HASENFUS, A., STÖCKLE, M., UNTEREGGER, G. and MENGER, M.D., 2015. Orthotopic tumorgrafts in nude mice: a new method to study human prostate cancer. The Prostate, vol. 75 , no. 14 , pp. 1526-1537. PMid:26074274. http://dx.doi. org/10.1002/pros.23027.

SARAMÄKI, A., BANWELL, C.M., CAMPBELL, M.J. and CARLBERG, C., 2006. Regulation of the human p21(waf1/ cip1) gene promoter via multiple binding sites for p53 and the vitamin D3 receptor. Nucleic Acids Research, vol. 34, no. 2, pp. 543-554. PMid:16434701. http://dx.doi.org/10.1093/nar/gkj460.

SMITH, D.C., JOHNSON, C.S., FREEMAN, C.C., MUINDI, J., WILSON, J.W. and TRUMP, D.L., 1999. A Phase I trial of calcitriol (1,25-dihydroxycholecalciferol) in patients with advanced malignancy. Clinical Cancer Research, vol. 5, no. 6, pp. 1339-1345. PMid:10389917.

STEBBING, J., PAZ, K., SCHWARTZ, G.K., WEXLER, L.H., MAKI, R., POLLOCK, R.E., MORRIS, R., COHEN, R., SHANKAR, A., BLACKMAN, G., HARDING, V., VASQUEZ, D., KRELL, J., ZACHAROULIS, S., CIZNADIJA, D., KATZ, A. and SIDRANSKY, D., 2014. Patient-derived xenografts for individualized care in advanced sarcoma. Cancer, vol. 120, no. 13, pp. 2006-2015. PMid:24705963. http://dx.doi.org/10.1002/ cncr.28696.

SUCKOW, M.A., DANNEMAN, P. and BRAYTON, C., 2001. The laboratory mouse. Boca Raton: CRC Press.

SWAMI, S., KRISHNAN, A.V., WANG, J.Y., JENSEN, K., HORST, R., ALBERTELLI, M.A. and FELDMAN, D., 2012. Dietary vitamin $\mathrm{D}_{3}$ and 1,25-dihydroxyvitamin $\mathrm{D}_{3}$ (calcitriol) exhibit equivalent anticancer activity in mouse xenograft models of breast and prostate cancer. Endocrinology, vol. 153, no. 6, pp. 2576-2587. PMid:22454149. http://dx.doi.org/10.1210/en.2011-1600.

SWAMI, S., RAGHAVACHARI, N., MULLER, U.R., BAO, Y.P. and FELDMAN, D., 2003. Vitamin D growth inhibition of breast cancer cells: gene expression patterns assessed by cDNA microarray. Breast Cancer Research and Treatment, vol. 80, no. 1, pp. 49-62. PMid:12889598. http://dx.doi.org/10.1023/A:1024487118457.

URATA, Y.N., LYRA, E.C., KATAYAMA, M.L., BASSO, R.A., ASSIS, P.E., CARDOSO, A.P., ROELA, R.A., NONOGAKI, S., SAMPAIO, G.J.C., BRENTANI, M.M. and FOLGUEIRA, M.A., 2014. Calcitriol supplementation effects on Ki67 expression and transcriptional profile of breast cancer specimens from post-menopausal patients. Clinical Nutrition, vol. 33, no. 1, pp. 136-142. http://dx.doi.org/10.1016/j.clnu.2013.04.001.

VERLINDEN, L., VERSTUYF, A., CONVENTS, R., MARCELIS, S., VAN CAMP, M. and BOUILLON, R., 1998. Action of $1,25(\mathrm{OH}) 2 \mathrm{D} 3$ on the cell cycle genes, cyclin D1, p21 and p27 in MCF-7 cells. Molecular and Cellular Endocrinology, vol. 142, 
no. 1-2, pp. 57-65. PMid:9783903. http://dx.doi.org/10.1016/ S0303-7207(98)00117-8.

WANG, D., VÉLEZ DE-LA-PAZ, O.I., ZHAI, J.X. and LIU, D.W., 2013. Serum 25-hydroxyvitamin D and breast cancer risk: a meta-analysis of prospective studies. Tumour Biology, vol. 34, no. 6, pp. 3509-3517. PMid:23807676. http://dx.doi.org/10.1007/ s13277-013-0929-2.

YIN, L., GRANDI, N., RAUM, E., HAUG, U., ARNDT, V. and BRENNER, H., 2010. Meta-analysis: serum vitamin D and breast cancer risk. European Journal of Cancer, vol. 46, no. 12, pp. 2196-2205. PMid:20456946. http://dx.doi.org/10.1016/j. ejca.2010.03.037.
ZHANG, X., CLAERHOUT, S., PRAT, A., DOBROLECKI, L.E., PETROVIC, I., LAI, Q., LANDIS, M.D., WIECHMANN, L., SCHIFF, R., GIULIANO, M., WONG, H., FUQUA, S.W., CONTRERAS, A., GUTIERREZ, C., HUANG, J., MAO, S., PAVLICK, A.C., FROEHLICH, A.M., WU, M.F., TSIMELZON, A., HILSENBECK, S.G., CHEN, E.S., ZULOAGA, P., SHAW, C.A., RIMAWI, M.F., PEROU, C.M., MILLS, G.B., CHANG, J.C. and LEWIS, M.T.A., 2013. renewable tissue resource of phenotypically stable, biologically and ethnically diverse, patientderived human breast cancer xenograft models. Cancer Research, vol. 73, no. 11, pp. 4885-4897. PMid:23737486. http://dx.doi. org/10.1158/0008-5472.CAN-12-4081. 